\title{
鼠 \\ PERSEPSI ANAK MUDA TERHADAP KEBERADAAN LANSIA DI INDONESIA
}

\author{
Adityo Nugroho ${ }^{1}$ \\ ${ }^{1}$ ERAT (Elderly Rights, Advocacy, \& Treatments) Indonesia \\ Email:simbahadit@gmail.com
}

\begin{abstract}
Abstrak
Indonesia akan mengalami peningkatan jumlah lansia dalam beberapa tahun ke depan. Kondisi ini akan memiliki dua implikasi sekaligus. Menjadi beban masyarakat dan negara, atau mampu berkontribusi positif. Apabila para lansia terus aktif dan bisa berdaya. Artikel ini berisi gambaran tentang persepsi anak muda terhadap keberadaan lansia. Baik dalam bentuk aktivitas, hak, serta peran negara. Penelitian dilakukan dengan sistem survai online. Responden sejumlah 347 anak muda berusia 16-30 tahun. Hasil penelitian menunjukan bahwa anak muda mendukung sepenuhnya berbagai aktivitas yang dilakukan lansia. Tapi kurang memahami akan adanya hak yang dimiliki para lansia. Anak muda juga menuntut peran serta negara dalam upaya memenuhi kesejahteraan lansia. Anak muda dengan karakteristiknya diharapkan mampu terlibat dalam upaya perlindungan terhadap lansia.
\end{abstract}

Kata Kunci : Anak Muda, Lansia, Aktivitas, Hak, Negara.

\begin{abstract}
Indonesia will experience an increase in the number of elderly in the next few years. This condition will have two implications at once. Being a burden on society and the country, or able to contribute positively. If the elderly continue to be active and can be empowered. This article contains an overview of young people's perceptions of the existence of the elderly. Both in the form of activities, rights, and the role of the state. The study was conducted with an online survey system. Respondents were 347 young people aged 16-30 years. The results showed that young people fully support various activities undertaken by the elderly. But do not understand the rights of the elderly. Young people also demand the participation of the state in efforts to meet the welfare of the elderly. Young people with their characteristics are expected to be able to be involved in protecting the elderly.
\end{abstract}

Keywords : Youth, Elderly, Activities, Rights, State. 


\section{LATAR BELAKANG}

Seperti dipaparkan Badan Pusat Statistik pada bagian pendahuluan Statistik Penduduk Lanjut Usia 2018, sebagai negara dengan jumlah populasi terbesar keempat di dunia menurut World Population Prospect 2017 Revision oleh Perserikatan BangsaBangsa (PBB), pertumbuhan penduduk Indonesia sangat berpengaruh terhadap komposisi penduduk dunia. Mulai tahun 2017 sampai 2050 diperkirakan separuh dari pertumbuhan penduduk di dunia hanya terkonsentrasi pada sembilan negara saja, termasuk Indonesia. Populasi dunia kini berada pada era penduduk menua (ageing population) dengan jumlah penduduk 60 tahun ke atas lebih dari $7 \%$ populasi. Seiring pertumbuhan penduduk tersebut, jumlah penduduk lansia makin lama juga meningkat dan memiliki kontribusi cukup tinggi terhadap pertumbuhan penduduk dunia secara keseluruhan. Populasi lansia mencapai 962 juta orang pada tahun 2017, dua kali lipat lebih dibanding tahun 1980 dengan 382 juta lansia di seluruh dunia. Angka yang diperkirakan akan terus meningkat pada tahun 2050 dengan prediksi mencapai sekitar 2,1 miliar lansia di seluruh dunia.

Lanjut usia sendiri atau kita sebut dengan lansia memiliki beberapa pengertian. WHO sebagai badan kesehatan dunia PBB memberikan pengertian lansia dalam empat kriteria, yaitu rentang 45-59 tahun merupakan usia pertengahan (middle age), rentang 60-74 tahun merupakan lanjut usia (elderly), rentang 75-90 tahun merupakan lanjut usia tua (old), sedangkan di atas 90 tahun merupakan usia sangat tua (very old). Indonesia sendiri mengacu pada Undang-Undang Nomor 13 Tahun 1998 tentang Kesejahteraan Lanjut Usia memberikan pengertian lansia sebagai seseorang yang telah mencapai usia 60 (enam puluh) tahun ke atas. Selain itu pemerintah juga menggolongkan lansia ke dalam beberapa kelompok umur, lansia muda dengan kisaran umur 60-69 tahun, lansia madya dengan kisaran umur 70-79 tahun, dan lansia tua umur 80 tahun ke atas.

Itu pengertian-pengertian jika kita menilik pada batasan-batasan lansia berdasarkan angka usia. Menarik jika kita melihat apa yang diungkapkan Gorman (1999) tentang definisi lansia. Terutama perbedaan akan pandangan dunia maju dan dunia berkembang. Bahwa proses penuaan merupakan realitas biologis yang memiliki dinamikanya sendiri, sebagian besar di luar kendali manusia. Namun juga tunduk pada konstruksi di mana setiap masyarakat memahami usia tua. Di negara maju, waktu kronologis memainkan peran penting. Usia 60 atau 65 tahun kira-kira setara dengan usia pensiun di sebagian besar negara maju, dikatakan sebagai awal usia tua. Di banyak bagian negara berkembang, waktu kronologis memiliki sedikit peran atau bahkan tidak penting dalam memaknai arti usia tua. Makna usia yang dikonstruksikan secara sosial lebih penting, seperti peran yang diberikan kepada orang yang lebih tua. Dalam beberapa kasus itu adalah hilangnya peran yang menyertai penurunan fisik yang signifikan dalam mendefinisikan usia tua. Maka berbeda dengan tonggak kronologis yang menandai tahap kehidupan di negara maju, usia lanjut di banyak negara berkembang dimulai pada titik ketika kontribusi aktif tidak lagi memungkinkan.

Kembali menurut Statistik Penduduk Lanjut Usia 2019 bahwa selama kurun waktu hampir lima dekade (1971-2019), persentase penduduk lansia Indonesia meningkat sekitar dua kali lipat. Pada tahun 2019, persentase lansia mencapai 9,6\% atau sekitar 25,64 juta orang. Kondisi demikian memperlihatkan bahwa Indonesia sedang bertransisi menuju ke arah penuaan penduduk karena persentase penduduk berusia di atas 60 tahun mencapai di atas 7\% dari keseluruhan penduduk dan akan menjadi negara dengan struktur penduduk tua (ageing population) jika sudah berada lebih dari $10 \%$. Kondisi ini tentunya akan mem- 
berikan dampak positif bagi negara bila mereka mampu berdayaguna. Dalam artian mampu mandiri, tidak menjadi beban bagi keluarga serta kelompok masyarakat yang lain, atau bahkan mampu memberi sumbangsih kepada negara.

Sebaliknya jika tidak terjaga dengan baik akan menimbulkan berbagai dampak negatif. Kondisi bertambahnya usia yang diiringi semakin rendahnya tingkat imunitas bisa menimbulkan berbagai permasalahan kesehatan. Kelalaian dalam menjaga kesehatan di kala muda akan berdampak besar kemudian hari di kala tua. Sektor ekonomi jelas lansia sudah memasuki masa akhir dalam segi pendapatan. Kebutuhan keseharian harus bisa mereka penuhi dari sisa-sisa tabungan maupun uang pensiun mereka sendiri. Apabila tidak mampu maka akan menjadi beban bagi keluarga yang menanggungnya. Sekalipun negara sebenarnya punya kewajiban akan hal ini. Segi sosial memerlihatkan bahwa dunia semakin cepat berkembang dan mayoritas lansia jarang bisa mengikuti perkembangannya. Perkembangan pengetahuan dan teknologi kekinian terus muncul merubah sendi-sendi kehidupan sosial. Beruntung bagi mereka yang bisa mengikuti atas dasar kemampuan sendiri ataupun pendampingan keluarga atau masyarakat. Sedang lainnya hanya bisa terkungkung dalam dunia yang tidak bisa lagi mereka jamah.

Pemerintah sendiri punya beberapa kebijakan terkait keberadaan lansia. Seperti tertuang dalam laporan Statistik Penduduk Lanjut Usia 2019 bahwa perhatian pemerintah terhadap kehidupan para lansia Indonesia diatur dalam Pasal 28H Ayat 2 Undang-Undang Dasar Negara Republik Indonesia Tahun 1945, yang menyatakan bahwa setiap orang berhak mendapatkan kemudahan dan perlakuan khusus untuk memperoleh kesempatan dan manfaat yang sama guna mencapai persamaan dan keadilan. Selanjutnya pada tahun 1998, perhatian ini diperkuat dengan diterbitkannya UU Nomor 13
Tahun 1998 tentang Kesejahteraan Lansia. Selain itu, Pasal 5 Ayat 3 Undang-Undang Nomor 39 Tahun 1999 tentang Hak Asasi Manusia menyatakan bahwa setiap orang termasuk kelompok masyarakat yang rentan berhak memperoleh perlakuan dan perlindungan lebih berkenaan dengan kekhususannya. Beberapa peraturan negara tersebut menyiratkan bahwa upaya pemenuhan dan penegakan Hak Asasi Manusia yang dilakukan oleh pemerintah harus bisa menjangkau seluruh lapisan masyarakat di Indonesia. Dalam hal ini termasuk perlakuan dan perlindungan khusus bagi para kelompok rentan, termasuk lanjut usia.

Adapun kebijakan lain juga tertuang dalam RPJMN 2015-2019 yang berfokus pada dua hal utama, yaitu peningkatan pemenuhan hak dasar dan inklusivitas serta penguatan skema perlindungan sosial bagi lansia. Pemerintah beserta Kementerian/ Lembaga terkait kelanjutusiaan juga sedang menyiapkan rancangan Strategi Nasional (Stranas) Kelanjutusiaan 2018-2025. Di dalamnya akan berisi lima hal pokok yang menjadi perhatian, yaitu pembangunan masyarakat dan SDM kelanjutusiaan, penguatan institusi pelaksana kelanjutusiaan, perlindungan sosial, jaminan pendapatan dan kapasitas individu, peningkatan derajat kesehatan lansia, serta perlindungan pemenuhan dan penghormatan terhadap hak lansia (Statistik Penduduk Lanjut Usia 2018). Selain itu juga terdapat kebijakan lain berkenaan dengan lansia seperti Program Keluarga Harapan (PKH) dan Kartu Keluarga Sejahtera (KKS) dari Kementrian Sosial, Bina Keluarga Lansia dari BKKBN, Bantuan Pangan non Tunai dari Sekretariat Direktorat Jenderal Penanganan Fakir Miskin, serta beberapa kebijakan turunan lainnya.

Meski begitu beberapa kebijakan pemerintah tersebut masih harus dicermati dengan seksama. Apakah berbagai program itu disusun berdasarkan kajian yang benar, bagaimana impelementasinya di lapangan, dan apakah sudah tepat sasaran 
seperti yang diharapkan. Patut dipertanyakan tatkala masih banyaknya berita tentang masih belum terpenuhinya hak para lansia yang menjadi kewajiban negara. Ketika negara masih dirasa kurang dalam memberikan jaminan terhadap lansia maka lingkup masyarakat harus turut serta dalam upaya ini, termasuk keluarga.

Dalam sebuah tatanan keluarga besar akan jamak dijumpai bertemunya tiga atau bahkan empat generasi dalam satu waktu. Termasuk di dalamnya adalah generasi lansia. Maka keluarga, dalam hal ini generasi di bawahnya memiliki peranan penting bagi lansia. Bukan berposisi sebagai penanggung beban hidup lansia, sebaliknya harus berperan untuk bisa mewujudkan lansia yang mandiri dan berdaya. Salah satu bagian dari generasi keluarga yang berpotensi akan hal ini adalah anak muda. Anak muda ini jika merunut pada UU No. 40 Tahun 2009 adalah mereka yang berusia 16-30 tahun. Dengan rentang usia mereka itu peluang untuk bertemu keluarga lansia sangat tinggi. Peluangnya ketika usia muda mereka bertemu lansia yang merupakan kakek nenek mereka, sedangkan selepas usia muda bertemu orangtua yang sudah masuk kategori lansia.

Kiprah anak muda sebagai agen perubahan (Sair, 2016) bagi kaum-kaum rentan sudah tak diragukan lagi. Baik secara personal ataupun berkelompok dalam komunitas/organisasi telah mampu bergerak dan menggerakan orang lain dalam upaya pemberdayaan kelompok rentan. Berbagai kelompok sasaran seperti anak-anak, difabel, dan lainnya sering mereka berdayakan. Baik melalui pendidikan, keterampilan, pelatihan, serta pendampingan lainnya. Sayangnya gerakan anak muda jarang menyasar lansia, ketika sebenarnya mereka setiap hari bersentuhan dengan satu kelompok sasaran ini. Fenomena ini harus segera diubah dengan memberikan kesadaran bagi anak muda akan pentingnya menjadikan lansia sebagai kelompok sasaran dalam pemberdayaan.
Sebelum masuk ke ranah pemberdayaan lansia oleh anak muda, pertanyaannya apakah mereka memahami konsep tentang lansia beserta hakhaknya. Maka perlu ada kajian awal atas persepsi anak muda terhadap isu-isu lansia itu sendiri. Harapannya ketika mereka sudah memahami konsep dan hak lansia maka pemberdayaan yang akan mereka lakukan tepat guna dan sasaran. Karena sekali lagi anak muda memiliki potensi yang besar untuk bisa menjadi pendamping lansia dalam melewati hari tua.

\section{METODE PENELITIAN}

Penelitian ini dilakukan oleh ERAT (Elderly Right, Advocacy, \& Treatments) Indonesia, dimana penulis menjadi bagian dari tim peneliti. ERAT Indonesia adalah perkumpulan yang bergerak dalam bidang penguatan hak dan treatment bagi Lansia Indonesia. Ini merupakan penelitian preeliminary untuk mengetahui pandangan dan pengalaman anak muda terkait beberapa hal dalam kehidupan, terutama yang berkaitan dengan warga berusia lanjut dalam kesehariannya.

Penelitian berlangsung selama kurang lebih dua minggu dari tanggal 25 Juli sampai 7 Agustus 2019. Penelitian memakai pendekatan metode kuantitatif, pengambilan data menggunakan sistem survai dengan kuesioner online. Menurut Singarimbun (2006) survai pada umumnya dibatasi pada penelitian yang datanya dikumpulkan dari sampel atau populasi untuk mewakili seluruh populasi. Dengan demikian, penelitian survai adalah penelitian yang mengambil sampel dari satu populasi dan menggunakan kuesioner sebagai alat pengumpulan data yang pokok. Sedangkan survai online menurut Bungin (2009) adalah cara pengumpulan data dalam proses survei yang dilakukan dengan menggunakan web atau email. Banyak keuntungan dalam penggunaan survei 
online dalam rangka meningkatkan fungsi dari sistem survai yang sudah ada sebelumnya. ERAT Indonesia sendiri menggunakan sistem ini untuk mendapat persebaran anak muda yang tinggal di berbagai daerah di Indonesia. Penggunaan sistem online juga mempermudah komunikasi dengan responden anak muda yang sudah sangat familiar dengan cara ini. Sisi lain guna menyiasati kendala waktu dan biaya yang harus dikeluarkan.

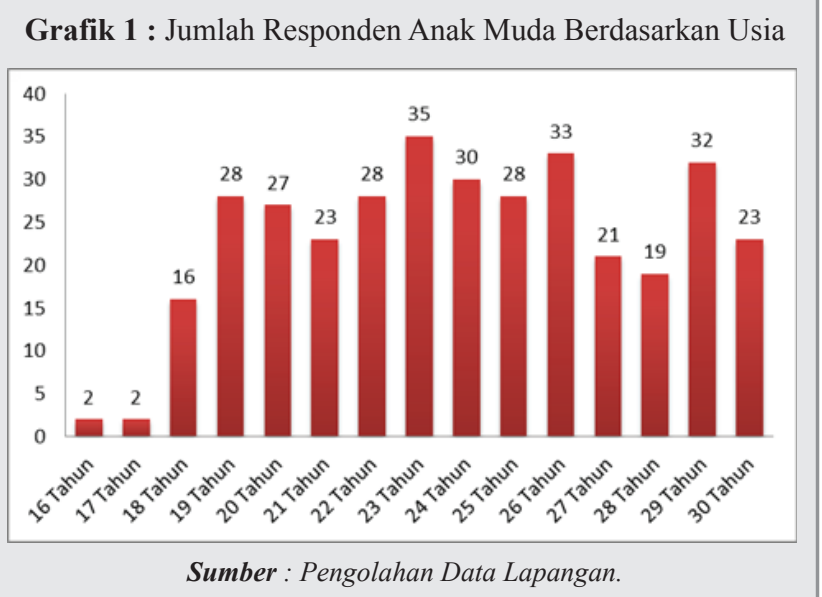

Responden dalam penelitian ini merupakan anak muda berusia 16-30 tahun, merujuk pada UU Kepemudaan No. 40 tahun 2009. Seleksi data yang masuk dilakukan untuk mengeliminasi responden yang kurang sesuai kriteria serta kelengkapan data. Hasilnya dalam survei online ini ada 347 anak muda yang masuk kriteria sebagai responden penelitian. Persebaran usia responden cukup merata, seperti tabel di atas. Dengan rerata 23,13 responden per satuan umur, respoden paling sedikit ada di usia awal anak muda (16 dan 17 tahun). Selepas usia itu jumlah responden bervariasi dari 16 sampai 35 orang.
Tabel 1 : Jumlah Responden Anak Muda Berdasarkan Lokasi Tinggal

\begin{tabular}{|l||c|l||c|}
\hline \multicolumn{1}{|c|}{ Provinsi } & Jumlah & \multicolumn{1}{c|}{ Provinsi } & Jumlah \\
\hline \hline Banda Aceh & 2 & Nusa Tenggara Barat & 1 \\
\hline \hline Sumatera Utara & 5 & Nusa Tenggara Timur & 1 \\
\hline \hline Sumatera Barat & 55 & Kalimantan Utara & 0 \\
\hline \hline Riau & 7 & Kalimantan Barat & 3 \\
\hline \hline Kepulauan Riau & 1 & Kalimantan Tengah & 3 \\
\hline \hline Jambi & 3 & Kalimantan Selatan & 3 \\
\hline \hline Bengkulu & 3 & Kalimantan Timur & 5 \\
\hline \hline Sumatera Selatan & 3 & Gorontalo & 0 \\
\hline Kepulauan Bangka Belitung & 1 & Sulawesi Utara & 3 \\
\hline \hline Lampung & 2 & Sulawesi Barat & 1 \\
\hline \hline Banten & 10 & Sulawesi Tengah & 2 \\
\hline \hline Jawa Barat & 26 & Sulawesi Selatan & 7 \\
\hline DKI Jakarta & 35 & Sulawesi Tenggara & 1 \\
\hline \hline Jawa Tengah Sumber : Pengolahan Data Lapangan. & 0 \\
\hline \hline DI Yogyakarta & 42 & Maluku Utara & 3 \\
\hline Jawa Timur & 96 & Maluku & 0 \\
\hline \hline Bali & 20 & Papua Barat & 2 \\
\hline
\end{tabular}

Demikian pula persebaran lokasi responden tersebar di 30 dari 34 provinsi di Indonesia. Meski begitu jumlah responden dari Pulau Jawa cukup mendominasi sebanding dengan jumlah penduduknya. Berturut-turut paling banyak asal lokasi tempat tinggal di Pulau Jawa adalah D.I. Yogyakarta dengan 96 responden, Jawa Tengah 42 responden, DKI Jakarta 35 responden, Jawa Barat 26 responden, Jawa Timur 20 responden, dan Banten 10 responden. Hanya Sumatra Barat provinsi luar Jawa yang menyumbang cukup banyak sejumlah 55 responden. Dari tabel di atas juga diketahui hanya 4 provinsi yang tidak terwakili responden anak muda, yaitu Kalimantan Utara, Gorontalo, Maluku Utara, dan Papua Barat.

\section{Lansia dan Pemuda di Indonesia}

Menurut Statistik Penduduk Usia Lanjut 2019 bahwa selama tahun 1971-2019 terlihat struktur usia penduduk di Indonesia mengalami perubahan dan bergeser menuju usia lanjut. Penduduk yang terlahir di era baby boom dan merupakan bonus demografi mulai bergeser menjadi penduduk usia produktif. Terus bergeser dan nantinya akan menjadi penduduk lansia. Pada tahun 2019, persentase lansia mencapai 9,6\% atau sekitar 25,64 juta orang. 
Setahun sebelumnya pada laporan yang sama tahun 2018 memproyeksikan pada tahun 2045 Indonesia akan memiliki sekitar 63,31 juta lansia atau hampir mencapai $20 \%$ populasi. Bahkan, proyeksi PBB juga menyebutkan bahwa persentase lansia Indonesia akan mencapai $25 \%$ pada tahun 2050 atau sekitar 74 juta lansia. Kedua proyeksi tersebut memperlihatkan bahwa akan ada kenaikan lebih dari 100\% jumlah lansia dalam kurun waktu 25-30 tahun mendatang. Kelak menjadikan Indonesia sebagai negara dengan struktur penduduk tua karena sudah kebih $10 \%$ dari total populasi.

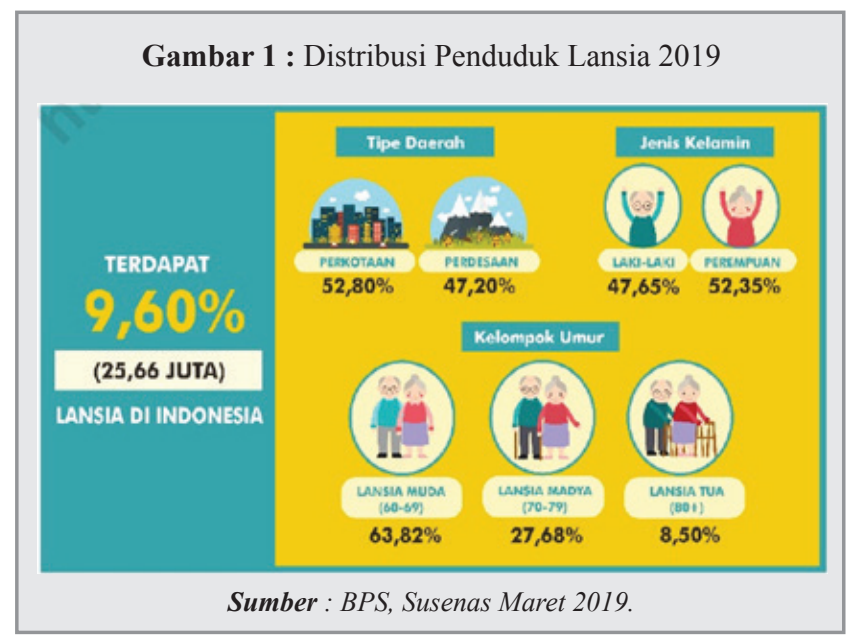

Gambar di atas merupakan distribusi penduduk lansia di Indonesia pada tahun 2019 yang diambil dari Statistik Penduduk Usia Lanjut 2019. Jika tempat tinggal lansia dibedakan dalam dua lokasi, maka lansia yang hidup di perkotaan $(52,8 \%)$ lebih banyak daripada di perdesaan $(47,2 \%)$. Jenis kelamin lebih banyak didominasi perempuan $(52,35 \%)$ daripada laki-laki (47,65\%). Sedangkan berdasarkan kelompok umur didominasi oleh lansia muda (63,82\%) dengan rentang umur 60-69 tahun. Sisanya merupakan lansia madya $(27,68 \%)$ dengan rentang umur 70-79 tahun dan lansia tua $(8,5 \%)$ yang berumur 80 tahun ke atas.

Jika mengacu pada data yang sama dari Susenas 2019, maka provinsi dengan persentase penduduk lansia terbanyak tahun 2019 adalah Daerah
Istimewa Yogyakarta (14,5\%) dan Jawa Tengah (13,36\%). Kemudian diikuti Jawa Timur (12,96\%), Bali $(11,3 \%)$, serta Sulawesi Utara $(11,15 \%)$. Menjadikan kelima provinsi tersebut sebagai penyumbang terbesar transisi Indonesia menuju ke arah penuaan penduduk karena persentase lansianya di atas $10 \%$.

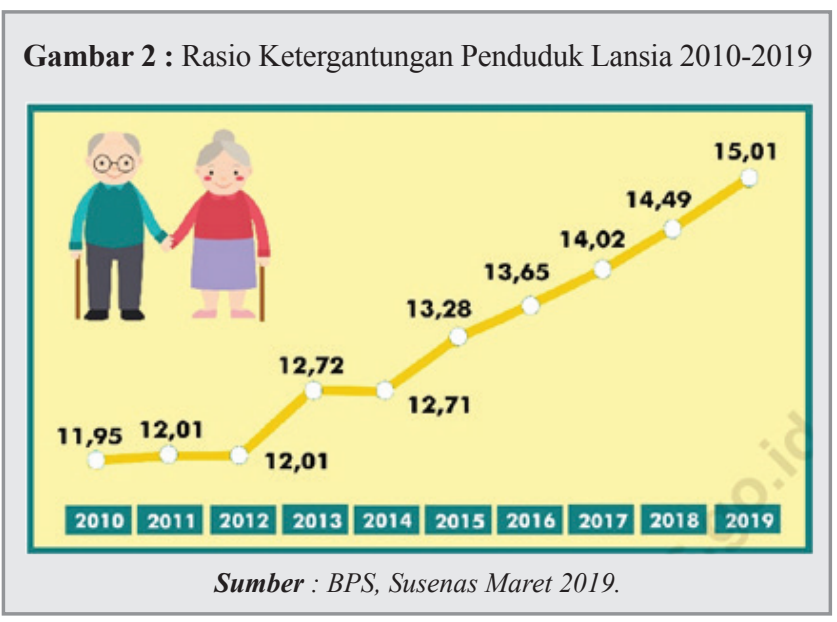

Grafik di atas memperlihatkan rasio ketergantungan lansia terhadap penduduk produktif. Terjadi peningkatan dari tahun 2010 sampai tahun 2019 . Lonjakan tidak begitu tinggi terjadi rentang waktu 2010 sampai 2014, dalam empat tahun hanya terjadi peningkatan dari 11,95 ke 12,71. Kenaikan berarti terjadi pasca tahun 2014 sampai 2019 hingga menyentuh angka 15,01. Angka ini menunjukan bahwa setiap 100 orang usia produktif (15-59 tahun) harus menanggung sekitar 15 lansia. Dari usia produktif tersebut sepertiganya adalah rentang usia anak muda (16-30 tahun). Tingginya jumlah lansia berpengaruh pada faktor kesehatan. Umumnya saat usia lansia mereka mengalami penuaan tubuh dan melemahnya sistem imun yang menjadi sebab munculnya penyakit. Maka tuntutan akan biaya perawatan cukup besar. Harusnya memang ini menjadi kewajiban negara untuk bisa menjamin hak para lansia, khususnya sektor kesehatan. Tetapi jika negara tidak mampu melaksanakan kewajibannya, maka beban itu teralihkan kepada penduduk usia produktif. 
Angka ketergantungan ini bukan menjadi suatu ancaman bila lansia dalam kondisi yang berdaya. Baik secara kesehatan atapun produktifitas. Bila kondisi ini tercapai maka akan memberikan dampak positif bagi masyarakat. Dan sudah sewajarnya hal ini diusahakan oleh lansia sendiri dengan didampingi kelompok usia produktif, termasuk anak muda.

Menurut Statistik Pemuda Indonesia 2019 yang dikeluarkan Badan Pusat Statistik (BPS) bahwa diperkirakan saat ini ada sekitar 64,19 juta jiwa pemuda yang tersebar di wilayah NKRI dan mengisi hampir seperempat jumlah penduduk Indonesia (24,01\%). Dampak program pengendalian jumlah penduduk sejak tahun 1970-an telah memberikan pengaruh tersendiri terhadap perubahan struktur umur penduduk. Selama delapan tahun terakhir persentase pemuda Indonesia cenderung stabil di angka 24\%. Pada pemuda persentase jumlah laki-laki (50,78\%) sedikit lebih tinggi dibandingkan perempuan $(49,22 \%)$. Data dari Susenas 2019 menunjukan persentase pemuda tertinggi berada di Papua dengan jumlah mencapai $26,38 \%$, terendah adalah Kepulauan Riau dengan $22,21 \%$.

Kaitannya dengan lokasi tinggal, jumlah pemuda di perkotaan $(57,94 \%)$ jauh lebih tinggi daripada yang tinggal di perdesaan $(42,06)$. Selain faktor lokasi asal, tingginya jumlah pemuda di perkotaan juga didorong faktor urbanisasi. Perpindahan anak muda ke lokasi tujuan ini dipengaruhi oleh beberapa faktor pendorong dan penarik. Salah satunya tentu impian akan kehidupan yang lebih baik terkait pekerjaan dan ekonomi. Termasuk kecenderungan mereka untuk menempati Pulau Jawa $(55,28 \%)$ dibandingkan Pulau Sumatra $(22,32 \%)$ dan pulau-pulau lainnya.

Berdasarkan hasil Susenas 2019, bahwa status tinggal pemuda dalam rumah tangga dibedakan menjadi tiga jenis, yaitu tinggal sendiri, bersama keluarga, dan lainnya. Status tinggal sendiri cukup jelas. Berstatus tinggal bersama keluarga jika pemuda tinggal bersama anak atau orang tua saja, baik itu didampingi pasangan maupun tidak. Sedangkan status tinggal dengan lainnya jika pemuda tinggal bersama tiga generasi atau keluarga lain.

\begin{tabular}{|c|c|c|c|c|}
\hline \multicolumn{5}{|c|}{$\begin{array}{c}\text { Tabel } 2 \text { : Persentase Pemuda Menurut Status Tinggal } \\
\text { dalam Rumah Tangga } 2019\end{array}$} \\
\hline $\begin{array}{c}\text { Karakteristik } \\
\text { Demografi }\end{array}$ & $\begin{array}{l}\text { Tinggal } \\
\text { Sendiri }\end{array}$ & $\begin{array}{l}\text { Bersama } \\
\text { Keluarga }\end{array}$ & Lainnya & Total \\
\hline (1) & (2) & (3) & (4) & (5) \\
\hline Total & 2,01 & 66,97 & 31,02 & 100,00 \\
\hline \multicolumn{5}{|l|}{ Tipe Daerah } \\
\hline Perkotaan & 3,16 & 66,69 & 30,15 & 100,00 \\
\hline Perdesaan & 0,43 & 67,35 & 32,22 & 100,00 \\
\hline \multicolumn{5}{|l|}{ Jenis Kelamin } \\
\hline Laki-laki & 2,28 & 67,54 & 30,18 & 100,00 \\
\hline Perempuan & 1,73 & 66,38 & 31,88 & 100,00 \\
\hline
\end{tabular}

Tabel di atas memperlihatkan bahwa mayoritas pemuda tinggal bersama keluarga $(66,97 \%)$ dan tingga bersama lainnya $(31,22 \%)$. Hal ini memperlihatkan bahwa tingginya potensi anak muda untuk bersentuhan langsung dengan lansia. Mereka memiliki peran cukup besar sebagai bagian dari unit sosial terkecil dalam masyarakat yang hidup dengan para lansia. Maka pandangan anak muda akan lansia ini menarik untuk dikaji dalam beberapa perspektif.

\section{Persepsi Anak Muda: Aktivitas Lansia}

Pertanyaan paling mendasar yang diajukan kepada anak muda adalah bagaimana pandangan mereka atas posisi kelompok lansia. Hal ini berkaitan dengan apakah anak muda memandang lansia seperti halnya kelompok masyarakat lain atau malah berbeda. Indikasinya bisa dilihat dari bagaimana anak muda melihat lansia dalam berbagai aktivitas. Adakah pandangan berbeda dari anak muda akan aktivitas yang dijalani lansia. Dari berbagai pertanyaan yang diajukan terkait aktivitas, hasilnya anak muda cenderung mendorong lansia untuk terus mengisi waktunya dengan berbagai kegiatan. 


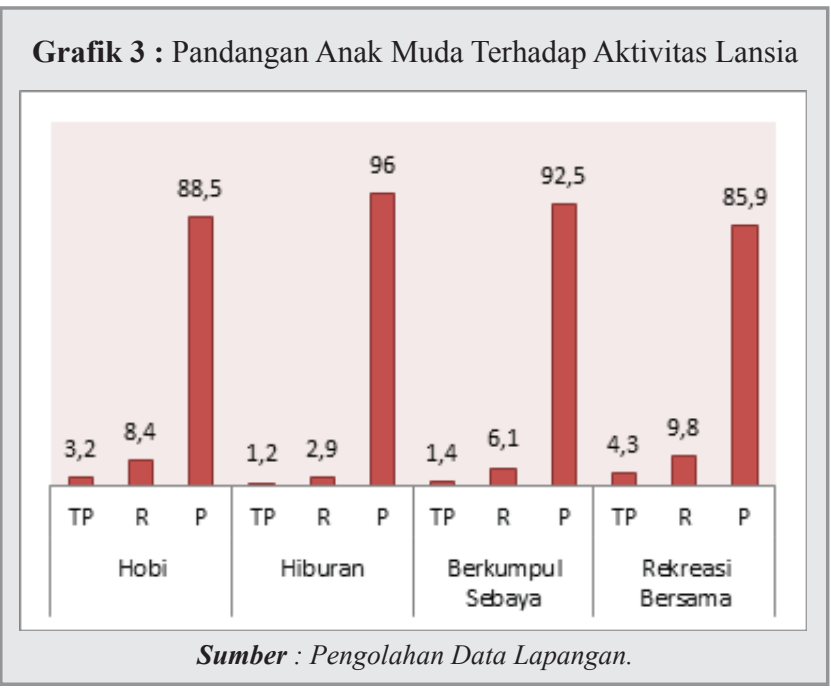

Grafik di atas memperlihatkan pandangan anak muda terkait berbagai kegiatan yang bisa dilakukan lansia. Pilihan jawaban dikelompokan menjadi tiga, yaitu tidak perlu (TP), ragu-ragu (R), dan perlu (P). Hasilnya sebanyak $88,5 \%$ merasa penting untuk lansia mengembangkan hobinya. Kegiatan ini bisa dilakukan sebagai salah satu kegiatan positif di masa tua. Menurut Lanawati dkk (2015) ketika memasuki usia pensiun dan menjadi warga senior, banyak lansia yang menjalani hidup monoton, hal ini yang menyebabkan lansia merasa perlu untuk mempunyai hobi agar tidak bosan. Berbagai macam hobi ini tentunya disesuaikan dengan kondisi lansia, misalnya seperti berkebun, menjahit, dan semacamnya.

Begitu pula sebanyak 96\% anak muda menganggap penting lansia untuk menikmati hiburan. Kegiatan-kegiatan yang bisa menimbulkan kebahagian seperti ini dibutuhkan lansia untuk mengisi hari-hari tuanya. Anak muda menganggap tidak ada yang membedakan lansia dengan golongan umur lain untuk tetap menikmati hiburan. Bagi lansia sendiri menikmati hiburan adalah salah satu cara untuk menghindari stress.

Termasuk salah satu aktivitas yang dirasa paling penting oleh anak muda adalah para lansia ini bisa berkumpul dengan rekan sebayanya. Hanya 1,4\% dari anak muda yang menganggap lansia berkumpul dengan teman sebaya tidak penting. Sedangkan $92.5 \%$ anak muda menganggap penting bagi para lansia untuk bisa berkumpul dengan rekan sebaya. Salah satu keterbatasan lansia untuk menjangkau generasi lain adalah perbedaan umur yang terpaut lumayan jauh. Perbedaan yang cukup jauh ini mempengaruhi pola pikir, kemampuan, serta pengetahuan terhadap sesuatu hal. Maka dengan berkumpul dengan sebaya menjadi salah satu opsi untuk bisa menikmati kegiatan secara bersama-sama. Termasuk salah satu yang bisa dilakukan lansia secara bersama-sama adalah rekreasi bersama, sebanyak $85,9 \%$ anak muda menyarankan para lansia untuk melakukan kegiatan ini. Bepergian dan menikmati kebersamaan dengan kelompok seusia akan memudahkan mereka untuk saling berbagi cerita dan gagasan.

Dari hasil di atas terlihat kecenderungan jawaban anak muda menganggap penting bagi lansia untuk tetap beraktivitas. Selain karena faktor kesehatan, aktivitas baik produktif ataupun hiburan dipandang anak muda menjadi salah satu kunci utama peran lansia di masyarakat. Ini penting karena dengan adanya nilai peran seorang lansia dalam kehidupan sosial maka dia akan dipandang ada, terlepas dari seberapa tinggi perannya.

\section{Persepsi Anak Muda: Hak Lansia}

Dalam laporan Lokataru Foundation berjudul "Para Lansia Bersatulah, Mengenal Konsep dan Hak Kaum Lansia” dijelaskan sejarah adanya hak bagi lansia. Dituliskan bahwa the rights of elderly person merupakan sebuah konsep yang kemunculannya ditandai dengan dirumuskannya Vienna International Plan of Action on Ageing (VIPAA) pada tahun 1982 oleh The Office of the High Commissioner for Human Rights (OHCHR). Jika ditelusuri lebih jauh lagi, acuan terhadap elderly person tidak terlepas dari Deklarasi Universal Hak Asasi Manusia (1948) yang mengisyaratkan bahwa semua manusia terlahir bebas dan setara 
dalam martabat dan hak, yang tentunya tidak akan berkurang ketika usia terus bertambah.

Hak lansia di Indonesia sendiri diatur dalam Undang-Undang Nomor 13 Tahun 1998 Pasal 5 Ayat 2. Isinya adalah sebagai penghormatann dan penghargaan kepada lanjut usia diberikan hak untuk meningkatkan kesejahteraan sosial yang meliputi pelayanan keagamaan dan mental spiritual, pelayanan kesehatan, pelayanan kesempatan kerja, pelayanan pendidikan dan pelatihan, kemudahan dalam penggunaan fasilitas, sarana, dan prasarana umum, kemudahan dalam layanan dan bantuan hukum, perlindungan sosial, serta bantuan sosial. Diperkuat dengan Undang-Undang Nomor 39 Tahun 1999 Pasal 5 Ayat 3 bahwa setiap orang yang termasuk kelompok masyarakat yang rentan berhak memperoleh perlakuan dan perlindungan lebih berkenaan dengan kekhususannya. Di mana lansia termasuk dalam kategori kelompok masyarakat rentan. Beberapa hak lansia yang menarik pada kajian perspektif anak muda ini adalah tentang bekerja dan belajar.

Berdasarkan laporan Statistik Penduduk Usia Lanjut 2019 bahwa pada tahun 2019 persentase lansia bekerja mencapai 49,39\%. Persentase tersebut cenderung stagnan dibandingkan tahun sebelumnya (49,79\%). Dengan kata lain, sekitar 1 dari 2 lansia masih bekerja di usia tuanya. Hal ini menunjukkan bahwa tidak sedikit penduduk usia lanjut yang tetap bekerja di hari tuanya.

Grafik 4 : Pandangan Anak Muda Terhadap Lansia Bekerja

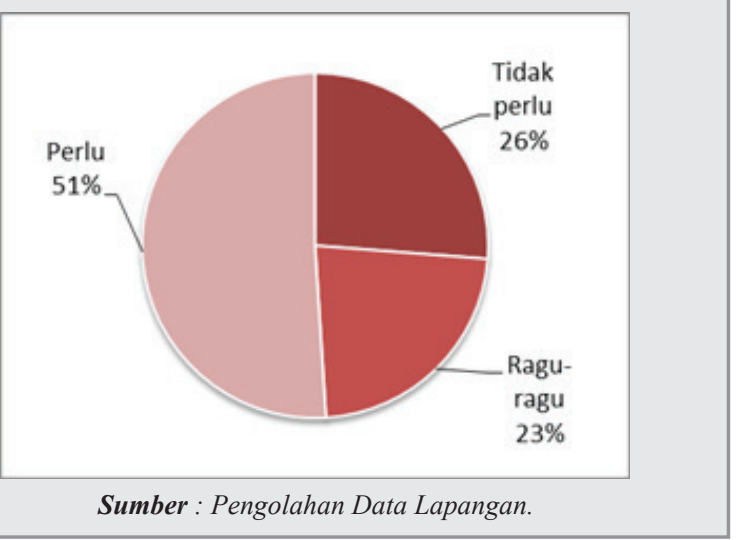

Diagram di samping memperlihatkan bahwa hanya separuh lebih sedikit atau hanya 51\% dari 347 anak muda yang menganggap lansia perlu bekerja. Sisanya menganggap para lansia sudah tidak perlu lagi melakukan kegiatan bekerja karena beberapa faktor seperti usia dan kesehatan. Hal ini diperkuat dari temuan data di pertanyaan terbuka yang diajukan kepada responden anak muda.

"Lansia tidak perlu susah payah mencari nafkah dan waktunya untuk menikmati hidup." (Mahasiswa, 19 tahun)

"Tidak perlu terlalu sibuk bekerja, istirahat dan nikmati waktu bersama anak dan cucu." (Mahasiswa, 22 tahun)

Dua pernyataan di atas mengisyaratkan bahwa anak muda sebenarnya cukup perhatian dengan kondisi lansia. Hanya saja mereka belum begitu memahami bahwa bekerja adalah merupakan hak bagi lansia. Selain itu ada faktor lain yang perlu diingat, bahwa tidak semua lansia berkecukupan di masa tua. Banyak dari mereka yang bekerja bukan hanya demi pemenuhan haknya saja, tapi juga mencari nafkah guna memenuhi kebutuhan hidup sehari-hari.

Jawaban yang sama didapatkan terkait kebutuhan lansia untuk belajar. Banyak anak muda yang menganggap lansia sudah tidak saatnya lagi belajar, bahkan hanya $28 \%$ yang menganggap itu penting. Anak muda cenderung melihat umur sebagai penghalang lansia untuk bisa berkecimpung di ruang-ruang belajar. Sama seperti kasus lansia bekerja, pemahaman anak muda terhadap belajar sebagai hak lansia masih kurang.

Persepsi anak muda terhadap lansia bekerja dan belajar ini sebenarnya menunjukan tren yang positif mengingat kepedulian mereka akan kondisi lansia. Walau kepedulian itu belum sepenuhnya ideal karena ekspresi penekanan yang berbeda. Hasil ini menunjukan bahwa anak muda masih belum memahami hak-hak kaum lanjut usia. Masih ada 


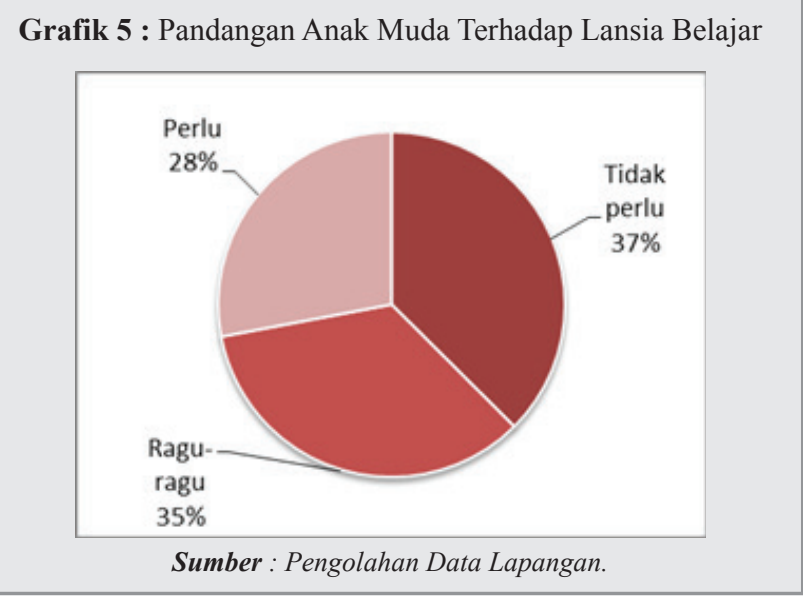

persepsi pembedaan kepada para lansia. Masih sedikit anak muda yang setuju ketika lansia tetap bekerja dan belajar. Padahal bekerja entah itu dalam kondisi apapun dan juga belajar adalah hak bagi setiap warga negara. Tak terkecuali bagi lansia.

\section{Persepsi Anak Muda: Peran Pemerintah}

Hasil pertanyaan terbuka pada penelitian ini menghasilkan beberapa pandangan anak muda terkait keberadaan lansia. Salah satu yang menonjol adalah persoalan peran pemerintah dalam upaya kesejahteraan lansia. Seperti dijelaskan di awal bahwa pemerintah punya kewajiban atas kesejahteraan dan pemenuhan hak-hak lansia. Responden anak muda dalam penelitian ini mengharapkan peran besar dari pemerintah dalam memberikan jaminan hidup bagi lansia.

"Dijamin kelangsungan hidupnya dan kebutuhannya khususnya terkait akses kesehatan yang lebih mudah lagi oleh negara."

(Mahasiswa, 25 tahun)

"Supaya kesehatan dan kebutuhan dasar mereka bisa dijamin oleh negara karena tidak banyak dari mereka yang masih mampu memenuhi kebutuhan hidupnya sendiri."

$$
\text { (Pekerja, } 26 \text { tahun) }
$$

"Bagian dari negara, mempunyai hak untuk dilindungi dan diberi fasilitas." (Mahasiswa, 26 tahun)
"Semoga selalu dilihat dan dijaga oleh negara melalui pemenuhan hak-hak untuk hidup."

(Pekerja, 21 tahun)

Beberapa keluaran data dari pertanyaan terbuka tersebut memperlihatkan responden anak muda memahami bahwa jaminan kesejahteraan lansia merupakan kewajiban pemerintah. Penekanannya pun beragam, seperti akses kesehatan yang tentunya para lansia membutuhkan posisi prioritas, penyediaan fasilitas penunjang bagi lansia sebagai bagian dari negara, sampai pada tuntutan pemenuhan hak hidup. Ada pula kesadaran bahwa tidak semua lansia mampu memenuhi kebutuhannya sendiri. Pemerintah secara program perencanaan melalui beberapa instansinya sudah mendesain berbagai kebijakan untuk lansia. Hanya saja kembali lagi, dampaknya belum begitu terlihat. Entah karena kebijakannya yang belum maksimal atau memang hanya menjadi prioritas kesekian.

Di sisi lain pemerintah bisa menggandeng kelompok anak muda untuk bisa memberdayakan lansia. Seperti dikutip dari Statistik Pemuda Indonesia 2019 bahwa pentingnya peran dan fungsi strategis dari pemuda disadari menjadi suatu perhatian bagi pemerintah. Kementerian lembaga terkait diharapkan dapat terus berusaha untuk melakukan pengembangkan potensi pemuda untuk bisa diberdayagunakan di berbagai bidang, sebagai langkah untuk menunjang pembangunan nasional. Termasuk di dalamnya bisa dilakukan pengembangan potensi anak muda yang sekaligus bisa menyejahterakan lansia. Berbagai program bisa dilakukan untuk membuat kegiatan yang mengkolaborasikan antara anak muda dan lansia. Aktivitas bersama dalam penelitian ini juga dipandang perlu bagi anak muda, sebanyak 69,2\% responden menganggap kegiatan bersama antar lansia dan anak muda perlu untuk dilakukan. Dalam aktivitas tersebut ada berbagai macam kegiatan positif yang bisa dilakukan, termasuk 
berbagi pengalaman dan pengetahuan antar mereka. Responden penelitian ini sebanyak 89,3\% juga menganggap perlunya berbagi pengetahuan modern kepada lansia.

\section{KESIMPULAN}

Anak muda memiliki kepedulian yang cukup besar terhadap lansia. Mereka mendukung berbagai macam aktivitas yang dilakukan oleh lansia. Mulai dari aktivitas yang menyangkut hobi, menikmati hiburan, aktivitas bersama rekan sebaya, dan rekreasi. Dukungan tanpa melihat status lansia sebagai golongan manusia berusia tua. Walau untuk urusan hak lansia sepertinya anak muda harus lebih banyak diberi pemahaman. Banyak anak muda yang masih ambigu akan keberadaan hak para lansia. Dalam bekerja dan belajar misalnya, anak muda cenderung merasa kedua hal tersebut tidak perlu dilakukan oleh lansia. Pandangan akan kesehatan lansia menjadi faktor utama mereka merasa keduanya tidak perlu dilakukan lansia. Di sini terlihat bahwa anak muda belum begitu paham terkait hak lansia, dimana hak bekerja dan belajar termasuk di dalamnya.

Anak muda juga mendorong pemerintah untuk berperan aktif dalam upaya mewujudkan kesejahteraan lansia. Mereka menilai lansia sebagai bagian dari penduduk suatu negara yang juga berhak memperoleh penghidupan yang layak. Bagi mereka banyak lansia masih belum bisa memenuhi kebutuhan hidup secara mandiri. Maka sudah selayaknya negara hadir untuk dapat membantu memenuhi kebutuhan hidup para lansia. Tidak menutup kemungkinan juga bagi pemerintah untuk dapat mendorong serta memfasilitasi anak muda untuk dapat beraktivitas bersama lansia. Sebagai upaya untuk saling berkomunikasi antar generasi, berbagi pengalaman dan pengetahuan antar keduanya.
Menjadi bahagia adalah kata kunci yang diutarakan anak muda kepada lansia, bukan sebuah slogan, namun pengharapan yang diraih melalui mekanisme personal, sosial dan kenegaraaan. Anak muda menilai lansia berhak untuk menyatatakan keunikan dan perbedaan dalam dirinya. Dan keluarga dipandang sebagai sumber utama bagi lansia untuk mendapatkan ruang-ruang tersebut, yang memuat penghargaan, penerimaan juga pendukungan kepada lansia. Lansia harus mendapatkan tempat dan perlindungan yang layak. Negara harus berperan aktif dalam memfasilitasi lansia. Bahkan memberikan kepastian bahwa seorang lansia yang tidak mampu secara ekonomi dan tak mampu bekerja, masih memiliki hak dan kesempatan untuk mendapatkan hidup layak dan bahagia. Generation gap menjadi jurang pemisah antara lansia dengan anak muda kini, terlebih dengan generasi milenial. Namun hasil kajian ini menemukan bahwa bagi anak muda, lansia bukanlah generasi yang berlawanan atau berseberangan. Betul ada perbedaan, namun beda itu tidak menjadikan perbedaan hakikat dan rasa sebagai manusia.

Penelitain ini cukup mewakili bagaimana persepsi anak muda akan keberadaan lansia di Indonesia. Sebagai suatu kajian awal untuk kemudian bisa dikembangkan menjadi kajian-kajian berikutnya atau malah diimplementasikan dalam suatu gerakan serta pembuatan kebijakan. Anak muda bisa menjadi kelompok usia yang bisa didorong kebermanfaatannya dalam pencapaian kesejahteraan bagi lansia. Mengingat dalam beberapa tahun ke depan Indonesia akan mengalami peledakan jumlah lansia. Sinergi dari berbagai pihak sangat dibutuhkan, termasuk dari negara dan anak muda itu sendiri. 


\section{DAFTAR PUSTAKA}

Affandi. Faktor-faktor yang Mempengaruhi Penduduk Lanjut Usia Memilih untuk Bekerja. Journal of Indonesian Applied Economics Volume 3, Nomor 2, 2009.

Agustina, Rida, et. al.. 2019. Statistik Pemuda Indonesia 2019. Jakarta: Badan Pusat Statistik.

Bungin, Burhan. 2009. Metodologi Penelitian Kuantitatif. Jakarta: Kencana.

Efendi, F., \& Makhfudli. 2009. Keperawatan Kesehatan Komunitas. Jakarta: Salemba Medika.

Gorman, M.. 1999. Development and the Rights of Older People. In: Randel J, et al., Eds. the Ageing and Development Report: Poverty, Independence, and The World's Older People. London: Earthscan Publications Ltd.

Lanawati, et. al.. Association of Physical Fitness Participation with Cognitive Function and Balance among the Elderly in Denpasar. Public Health and Preventive Medicine Archive (PHPMA) Volume 3, Nomor 2, 2015.

Maryam, R. S., et. al.. 2008. Mengenal Usia Lanjut dan Perawatannya. Jakarta: Salemba Medika.

Maylasari, Ika, et. al.. 2019. Statistik Penduduk Usia Lanjut 2019. Jakarta: Badan Pusat Statistik.

Nugroho, Adytio, et. al.. 2020. Para Lansia Bersatulah, Mengenal Konsep dan Hak Kaum Lansia. Jakarta: Lokataru Foundation.

Pandji, Dewi. 2012. Menembus Dunia Lansia. Jakarta: Elex Media Komputindo.

Qureshi, Hazel, \& Walker, Alan. 1989. The Caring Relationship: Elderly People and their Families. London: The Macmillan Press Ltd.

Silviliyana, Mega, et. al.. 2018. Statistik Penduduk Usia Lanjut 2018. Jakarta: Badan Pusat Statistik.

Sair, Abdus. 2016. Kampus dan Degradasi Pengetahuan Politik Mahasiswa. Jurnal Sosiologi Pendidikan Humanis; Volume 1 No 1 Tahun 2016

Suharko, (ed). 2006. Gerakan Sosial: Konsep, Strategi, Aktor, Hambatan, dan tantangan Gerakan Sosial di Indonesia. Malang: Averroes Press.

\section{Peraturan Perundang-Undangan}

Undang-Undang Dasar Negara Republik Indonesia Tahun 1945 Pasal 28H Ayat 2.

Undang-Undang Nomor 13 Tahun 1998 tentang Kesejahteraan Lanjut Usia.

Undang-Undang Nomor 39 Tahun 1999 tentang Hak Asasi Manusia.

Undang-Undang Nomor 40 Tahun 2009 tentang Kepemudaan.

\section{Website}

https://www.who.int/healthinfo/survey/ageingdefnolder/en/ https://kemsos.go.id/hobi-dan-kebahagiaan-lansia 